\title{
6. CAPILLARY-PRESSURE CHARACTERISTICS AND PORE-SYSTEM EVOLUTION OF MESOZOIC AND TERTIARY CARBONATES FROM THE EXMOUTH PLATEAU AND THE ARGO AND GASCOYNE ABYSSAL PLAINS ${ }^{1}$
}

\author{
David C. Kopaska-Merkel 2,3
}

\begin{abstract}
The capillary-pressure characteristics of 22 samples of lithified post-Paleozoic Indian-Ocean carbonates were compared to published data from older carbonate rocks (lower Paleozoic Hunton Group of Texas and Oklahoma). The Indian-Ocean samples are considerably more porous than are the Paleozoic samples, yet all of the Indian-Ocean samples fit readily into a descriptive petrofacies scheme previously established for the Hunton Group. The Indian-Ocean samples may be assigned to four petrophysical facies (petrofacies) based on the shapes of their capillary-pressure curves, their pore-throat-size distributions, their estimated recovery efficiency values (for nonwetting fluids), and the visual characteristics of their pore systems, as observed with a scanning-electron microscope.

Petrofacies assignments for the Indian-Ocean samples are as follows. Petrofacies I includes six samples collected from the coarse basal portions of event deposits (primarily turbidites). These samples have large throats, leptokurtic throat-size distributions, low- to moderate recovery efficiency values, concave cumulative-intrusion capillary-pressure curves, and high porosity values. Petrofacies II includes two sedimentologically dissimilar samples that have medium-size throats, platykurtic throat-size distributions, moderate- to-high recovery efficiency values, gently sloping cumulative-intrusion capillary-pressure curves, and high porosity values. Petrofacies III includes two polymictic sandstones and a skeletal packstone that have small throats, polymodal throat-size distributions, moderate recovery efficiency values, gently sloping cumulative-intrusion capillary-pressure curves, and high porosity values. Petrofacies IV includes 11 samples, mostly recrystallized neritic carbonates, that have small throats, leptokurtic throat-size distributions, high recovery efficiency values, convex cumulative-intrusion capillary-pressure curves, and low porosity values.

Comparison of petrofacies assignment to core-, thin-section-, and smear-slide data, and to inferred depositional setting, suggests that pore systems in most samples from Holes $765 \mathrm{C}$ and $766 \mathrm{~A}$ result from primary depositional features, whereas pore systems in samples from Hole $761 \mathrm{C}$ and one sample from Hole $765 \mathrm{C}$ have been strongly influenced by diagenetic processes. For Hole 761C, prediction of petrophysical parameters should be most successful if based on diagenetic facies patterns. By contrast, the distribution of favorable reservoir facies and of permeability barriers in less highly altered rocks collected from Holes $765 \mathrm{C}$ and $766 \mathrm{~A}$ is related to depositional patterns.

Recovery efficiency is inversely related to both porosity and median throat size for the present data set. This relationship is similar to that observed for carbonates of the lower Paleozoic Hunton Group and the Ordovician Ellenburger dolomite, but opposite of that observed for some other ancient carbonates.

The coarse deposits of the massive basal units of turbidites are petrophysically distinct and form a coherent petrophysical group (Petrofacies I) with substantial reservoir potential. Two samples assigned to Petrofacies I have extremely large throats (median throat size at least $4 \mu \mathrm{m}$, and at least six times that of any other sample) and therefore high permeability values. These two samples come from thin, coarse turbidites that lack or have poorly developed fine divisions and are interpreted to have been deposited on channeled suprafan lobes in a proximal mid-fan setting. The restriction of extremely high permeability values to a single depositional facies suggests that careful facies mapping of deep-sea fans in a deliberate search for such coarse turbidites could dramatically enhance the success of exploration for aquifers or hydrocarbon reservoirs. Such reservoirs should have substantial vertical heterogeneity. They should have high lateral permeability values but low vertical permeability values, and reservoir sections should include numerous thin units having widely differing petrophysical characteristics.
\end{abstract}

\section{INTRODUCTION}

Among the fundamental physical properties of sedimentary rocks, the characteristics of pore systems are important because pore systems control the amount of fluid (usually brine or hydrocarbons) that may be stored within the rock. Pore-system characteristics also control the conditions under which stored fluids may flow out of or into the rock, or become trapped within the rock. Pore systems in sedimentary rocks are products of the depositional fabrics of the preexisting sediments (as well as of micropo-

\footnotetext{
${ }^{1}$ Gradstein, F. M., Ludden, J. N., et al., 1992. Proc. ODP, Sci. Results, 123 : College Station, TX (Ocean Drilling Program).

2 Northeastern Science Foundation, P.O. Box 746, Troy, NY 12181-0746, U.S.A.

3 Present address: Energy and Coastal Geology Div., Geol. Surv. of Alabama, 420 Hackberry Lane, P.O. Box O, Tuscaloosa, AL 35486-9780, U.S.A.
}

rosity within sedimentary particles), modified by diagenesis. Porosity is reduced or destroyed by cementation, pressure-solution, and compaction and is created or enlarged by dissolution. All of these processes, in addition to changing the total volume of the pore system, may alter the shapes and sizes of the individual pore spaces, and even the electrochemical characteristics of the rock surfaces forming the walls of the pore system. All of these changes affect the movement of fluids, including brines, freshwater, and hydrocarbons.

The purpose of this chapter is to describe and interpret the pore-system characteristics of lithified carbonates underlying the Wombat Plateau and underlying the Argo and Gascoyne abyssal plains (Leg 123 Shipboard Scientific Party, 1988; von Rad et al., 1989; Ludden, Gradstein, et al., 1990, and references cited therein). This was done for three reasons: (1) as already mentioned, pore-system characteristics control the storage and movement of fluids in rocks, and the study area has substantial hydro- 
carbon-production potential; (2) the pore-system characteristics of a rock, because they are the products of depositional conditions and diagenetic processes, provide a valuable source of information for sedimentologic and diagenetic studies; (3) no study such as the one reported here has ever been undertaken on rocks underlying any of the modern ocean basins. The results therefore provide the beginnings of a baseline study that may be compared to data derived from studies of older rocks.

Thirty samples were collected from Sites 761, 765, and 766, drilled during Legs 122 and 123 , and 22 of these (some from each site) were sufficiently lithified for analysis by mercury porosimetry (described in "Petrophysical Analysis" section, this chapter). Site 761 is located on the Wombat Plateau, which was a shallow marine platform in the late Triassic when the rocks sampled for this study were deposited (von Rad et al., 1989). Site 765 is located near the center of the Argo Abyssal Plain, near the Wombat Plateau, but was more directly influenced by a major submarine fan heading in Swan Canyon, east of the Wombat Plateau, when the rocks sampled for this study were deposited (Aptian to middle Miocene) (Leg 123 Shipboard Scientific Party, 1988; von Rad et al., 1989). Site 766 lies in the Gascoyne Abyssal Plain, at the foot of an escarpment on the west side of the Exmouth Plateau (Leg 123 Shipboard Scientific Party; von Rad et al., 1989). The samples described here are dominated by sedimentary particles shed from the shallow marine top of the Exmouth Plateau over its western escarpment.

Capillary-pressure data were generated for each of the 22 samples using mercury porosimetry. The samples were then classified according to a simple descriptive scheme (Kopaska-Merkel and Friedman, 1989). Scanning-electron microscopic examination of representative samples was used to calibrate the capillarypressure data to pore-system origin, geometry and surface roughness. Pores were classified using the classification of Choquette and Pray (1970). The results of these analyses were compared with sedimentologic, stratigraphic, petrographic, physical, and chemical data to determine what factors controlled the development of pore systems in these rocks and to determine the causes of petrophysical similarities and differences among the samples.

Samples from Sites 765 and 766 are poorly lithified because of limited interparticle cementation, and therefore the pore-system characteristics of these samples are primarily determined by depositional and very early post-depositional processes. By contrast, the samples from Site 761 are well lithified, and the pore systems have been considerably altered by cementation and recrystallization. In a few cases, widely differing depositional and diagenetic histories produced nearly identical capillary-pressure characteristics.

\section{MATERIALS AND METHODS}

\section{Sample Locations}

Samples ranging in age from Triassic to middle Miocene were collected from Sites 761, 765, and 766 (Table 1). One of the two analytical methods used in this study (mercury porosimetry) will produce meaningful data only if samples retain their fabric and are not crushed or broken in any way when subjected to substantial fluid pressures $(20,000$ psia air- $\mathrm{Hg}$, in the case of this study). Therefore, unlithified and marginally lithified materials could not be studied. Rates and times of lithification are commonly strongly dependent on sediment characteristics, and this was the case for Sites 765 and 766 (Ludden, Gradstein, et al., 1990). Therefore, the samples used in this study are of necessity a biased sample of the sedimentary materials penetrated by drilling in Holes $765 \mathrm{C}$ and $766 \mathrm{~A}$.

All but two samples analyzed from Hole $765 \mathrm{C}$ are relatively coarse chalks from the lower divisions (division A, Bouma, 1962) of carbonate turbidites. Thus, although only a restricted part of the observed range of lithologies could be studied, the samples from Hole $765 \mathrm{C}$ are comparable to one another. The two samples from Hole $766 \mathrm{~A}$ are both polymictic sandstones from the lower divisions of graded sequences, which are probably turbidites. Thus, sediments sampled from Holes $765 \mathrm{C}$ and $766 \mathrm{~A}$ were formed under similar depositional conditions and have similar particle sizes, although mineral composition of particles differs considerably between the two holes (calcareous vs. polymictic, but dominantly siliceous). The similarity of depositional conditions and particle sizes for samples analyzed from Holes $765 \mathrm{C}$ and $766 \mathrm{~A}$ permits an in-depth analysis of pore-system characteristics of poorly lithified sand-size sediments forming the bases of turbidites in two different depositional settings.

Sediments encountered in Hole $761 \mathrm{C}$ had been more thoroughly lithified, and most materials making up the stratigraphic

Table 1. Sample data for all 22 samples analyzed.

\begin{tabular}{|c|c|c|c|c|}
\hline Hole & Sample & Age & Depth (mb & Lithology \\
\hline $761 \mathrm{C}$ & 23R-1, 33-35 cm & Rhaetian & 337.54 & Fossiliferous wackestone \\
\hline $761 \mathrm{C}$ & $23 \mathrm{R}-1,127-130 \mathrm{~cm}$ & Rhaetian & 338.48 & Fossiliferous wackestone \\
\hline $761 C$ & 23R-2, $108-111 \mathrm{~cm}$ & Rhaetian & 339.79 & Fossiliferous wackestone \\
\hline $761 \mathrm{C}$ & $24 \mathrm{~A}-1,80-82 \mathrm{~cm}$ & Rhaetian & 347.51 & Fossiliferous wackestone \\
\hline $761 \mathrm{C}$ & 24R-2, 78-81 cm & Rhaetian & 349.00 & Fossiliferous bioturbated mudstone \\
\hline $761 \mathrm{C}$ & 26R-3, $90-92 \mathrm{~cm}$ & Rhaetian & 369.61 & Fossiliferous bioturbated mudstone \\
\hline $761 \mathrm{C}$ & $26 \mathrm{R}-5,30-32 \mathrm{~cm}$ & Rhaetian & 372.01 & Fossiliferous bioturbated mudstone \\
\hline $761 \mathrm{C}$ & $27 \mathrm{R}-1,34-36 \mathrm{~cm}$ & Rhaetian & 375.55 & Fossiliferous wackestone \\
\hline $761 \mathrm{C}$ & $31 \mathrm{R}-2,85-87 \mathrm{~cm}$ & Rhaetian & 410.56 & Oolitic fossiliferous grainstone \\
\hline $761 C$ & $32 \mathrm{R}-2,32-34 \mathrm{~cm}$ & Norian & 419.53 & Graded fossiliferous packstone \\
\hline $761 \mathrm{C}$ & $32 \mathrm{R}-2,124-126 \mathrm{~cm}$ & Norian & 420.45 & Graded pack-wackestone \\
\hline $765 \mathrm{C}$ & $5 \mathrm{R}-1,57 \mathrm{~cm}$ & middle Miocene & 389.17 & Foraminiferal chalk, thin turbidite \\
\hline $765 \mathrm{C}$ & 7R-2, $103-104 \mathrm{~cm}$ & middle Miocene & 410.54 & Foraminiferal chalk, turbidite base \\
\hline $765 C$ & $9 \mathrm{~A}-3,76-79 \mathrm{~cm}$ & middle Miocene & 431.08 & Calcareous chalk, turbidite base \\
\hline $765 \mathrm{C}$ & $12 \mathrm{R}-3,142-144 \mathrm{~cm}$ & middle Miocene & 459.63 & Clayey calcareous chalk, thin turbidite \\
\hline $765 \mathrm{C}$ & $19 R-3,63-66 \mathrm{~cm}$ & early Eocene & 524.94 & Calcareous chalk, turbidite \\
\hline $765 \mathrm{C}$ & $35 \mathrm{R}-2,110-112 \mathrm{~cm}$ & Aptian & 676.70 & Calcareous chalk, cross-laminated division, turbidite \\
\hline $765 C$ & $36 \mathrm{R}-2,21-23 \mathrm{~cm}$ & Aptian & 685.02 & Calcareous chalk, laminated turbidite base \\
\hline $765 \mathrm{C}$ & $38 \mathrm{R}-3,50-52 \mathrm{~cm}$ & Aptian & 706.01 & Silty calcareous fragment mixed sediment, turbidite \\
\hline $765 \mathrm{C}$ & $39 \mathrm{R}-3,57-59 \mathrm{~cm}$ & Aptian & 715.28 & Calcareous chalk, turbidite base \\
\hline $\begin{array}{l}766 \mathrm{~A} \\
766 \mathrm{~A}\end{array}$ & $42 \mathrm{R}-4,83-85 \mathrm{~cm}$ & Hauterivian & 399.14 & Polymictic sandstone, turbidite base \\
\hline $766 \mathrm{~A}$ & $43 \mathrm{R}-3,66-68 \mathrm{~cm}$ & Hauterivian & 407.17 & Polymictic sandstone, turbidite base \\
\hline
\end{tabular}


interval of interest were suitable for mercury porosimetry. The 11 samples from Hole $761 \mathrm{C}$ therefore are representative of the interval studied and permit investigation of the effects of differing sediment characteristics on pore-system evolution, under relatively homogeneous diagenetic conditions. The samples range from bioturbated fossiliferous mudstone to oolitic and skeletal grainstone (see Table 1).

\section{Petrophysical Analysis}

A brief introduction to petrophysical analysis in general, and to mercury porosimetry in particular, is included here because the concepts involved, which must be understood for the results of this study to make sense, may be unfamiliar to some readers. The discussion is modified from Kopaska-Merkel and Friedman (1989).

The pore system in a rock consists of two elements: the main open spaces (pores) and the smaller channels (pore throats or throats) connecting the pores. The definition is simple, but the total characterization of pore systems is difficult because of their complexity (see Appendix for definitions of terms). Pore-system geometry and topology control the movement and distribution of fluids within porous media, such as hydrocarbon reservoirs. Using capillary-pressure curves derived from mercury porosimetry, one can estimate petrophysical parameters, such as throat-size distribution, effective porosity, and recovery efficiency (Purcell, 1949; Smith, 1966; Dullien and Dhawan, 1974; Wardlaw, 1976; Schowalter, 1979; Van Brakel et al., 1981; Wardlaw and McKellar, 1981; Jennings, 1987; Kopaska-Merkel and Friedman, 1989). Permeability may be estimated from capillary-pressure data (Jennings, 1987), but only if throats are large and well-"sorted," microporosity is negligible, and permeability is greater than approximately $1 \mathrm{md}$. Only two of the samples described here meet these criteria (Samples 123-765C-5R-1, $57 \mathrm{~cm}$, and -12R-3, 142$144 \mathrm{~cm}$ ) and therefore permeability was not estimated in this study.

Before briefly discussing the method of mercury porosimetry, I must make a distinction between wetting fluids and nonwetting fluids. All fluids experience surface tension, the stress on the surface of a liquid caused by Van der Waals forces that are not opposed by intermolecular agitation (Levorsen, 1967; p. 442). The surface tension of a fluid, as well as its interfacial tension with coexisting fluids, determines its contact angle with the surface of its enclosing porous medium (here, sedimentary rock). If the fluid adheres strongly to the rock surface, then the contact angle (measured through the fluid) is low, and the rock-fluid contact is classified as wetting. If the fluid is repelled by the rock surface and the contact angle is high, then the contact is nonwetting. Wetting fluids coat the rock surfaces and flow readily through any openings sufficiently larger than their component molecules. Nonwetting fluids "bead up" on rock surfaces, and are subject to capillary forces, which means that pressure must be applied to force them through small openings. The pressure required is inversely proportional to the size of the opening. Because mercury is a nonwetting fluid, mercury capillary-pressure data produce information directly relevant to the behavior of nonwetting fluids. In natural rock systems, either water or petroleum may behave as a nonwetting fluid, depending on the nature of the rock matrix, any organic- or inorganic coatings on the rock, coexisting fluids, fluid characteristics, and the characteristics of other materials mixed with any of the fluids (e.g., detergents). Carbonate rocks may be oil-wet or water-wet in roughly equal proportions. This discussion is abstracted from more comprehensive treatments in Levorsen (1967), Wardlaw (1976, 1980), Good and Mikhail (1981), Yu and Wardlaw (1986a, 1986b), Yu et al. (1986), and Ghosh and Friedman (1989).
Mercury porosimetry involves measuring the volume distribution of pore throats. Pore throats constitute only a small fraction of the total pore-system volume. However, most mercury-porosimetry studies give information about only the pore throats (Wardlaw, 1976) because the method depends on the forcing of mercury into the small voids within the rock. The smallest voids (throats) control access to the larger ones (pores) because higher pressures are needed to force mercury or other nonwetting fluids into smaller spaces (principle of capillarity; see, e.g., Purcell, 1949). Pore throats are the bottlenecks in the pore system; their critical capillary pressures must be exceeded for mercury or other nonwetting fluids to enter the pores they surround. For an infinite sample with a spatially homogeneous pore system, the total volume of mercury intruded at a given pressure is precisely related to the number of throats of corresponding size. Thus, a graph of cumulative mercury-intrusion volume vs. capillary pressure is equivalent to cumulative mercury-intrusion volume vs. porethroat size. More precisely, the experimentally derived number associated with pore throats of a given size is the total volume of pore space filled through throats of that size.

The particular pore-throat size (calculated) corresponding to a given pressure (measured) depends on the model of throat geometry used (Wardlaw and Taylor, 1976; Dullien, 1979), as well as on the mercury contact angle and on the values for interfacial tension of mercury and air. The model used here is that of Wardlaw (1976; Wardlaw and Taylor, 1976) in which throats are assumed to be sheetlike (Wardlaw, 1976). This model was chosen for reasons discussed by Kopaska-Merkel and Friedman (1989), but may be inappropriate for pore systems dominated by interparticle porosity. Several samples analyzed in this study have considerable interparticle porosity, and for these samples, the correct pore-throat sizes may be as much as twice the values reported. In our model, throat size $(d)$ is calculated by the equation

$$
d=(-2 \gamma \cos \theta) / p
$$

where $\gamma$ is the interfacial tension (485 dynes/cm for $\mathrm{Hg} /$ vacuum), $\theta$ is the contact angle $\left(130^{\circ}\right.$ for $\mathrm{Hg} /$ vacuum, measured in $\mathrm{Hg}$ ), and $p$ is the pressure (in psia). A contact angle of $130^{\circ}$ was chosen for reasons discussed by Kopaska-Merkel and Friedman (1989).

All samples were run on a Micromeritics pore sizer 9305, and the data were reduced using RUN9305.BAS, v. 1.03, the program supplied with the machine (Micromeritics manual, pore sizer 9305, 1983; Kopaska-Merkel et al., 1987; Kopaska-Merkel and Amthor, 1988). The experimental pressure range (1.5 to 20,000 psia or 0.01 to $138 \mathrm{MPa}$ ) was greater than that used by other scientists. Rock samples were tested at high pressures (1) to duplicate subsurface conditions at realistic depths and (2) to evaluate the full range of available porosity in the rocks studied, some of which contain large pore-system volumes that might remain undetected at substantially lower pressures. A pressure of $20,000 \mathrm{psia}(138 \mathrm{MPa}$ ) air-Hg equals roughly $4000 \mathrm{psia}(28 \mathrm{MPa})$ in nature, which is comparable to the hydrostatic pressure at a depth of $1.7 \mathrm{mi}(2.8 \mathrm{~km})$ or less (Purcell, 1949; Smith, 1966; Schowalter, 1979). Thus, the experimental pressure range covered the entire range of hydrostatic pressures experienced in the subsurface by the studied rocks. Use of mercury capillary pressures as high as those reported here rarely affects data quality by damaging the rock samples (Kopaska-Merkel, 1991).

Sample (core plug) sizes were more than sufficient to yield accurate data using the available equipment (Purcell, 1949; Larson and Morrow, 1981; Ghosh et al., 1987; Kopaska-Merkel, 1988).

Scales on all SEM photomicrographs are in micrometers. 


\section{RESULTS}

\section{Site 765, Cretaceous and Tertiary Carbonate Turbidites}

Nine samples of lithified carbonate sediment from Hole 765C, ranging in age from early Aptian to middle Miocene, were analyzed (see Table 1). These samples were collected from lithologic Subunits IIB, IIIA, IVC, and IVD (Ludden, Gradstein, et al., 1990, fig. 10, p. 77). All but two samples consist of sand- or silt-size calcareous chalk or sand-size foraminiferal chalk. One is a silty calcareous-fragment mixed sediment, and one is a clayey calcareous chalk. Six of the nine samples were collected from the coarse basal divisions of carbonate turbidites (Ludden, Gradstein, et al., 1990). Most of these rocks are massive, but Sample 123-765C$36 \mathrm{R}-2,21-23 \mathrm{~cm}$, collected from a turbidite that lacked a massive unit, is laminated. One sample is from the cross-laminated division of a carbonate turbidite (Sample 123-765C-35R-2, 110-112 $\mathrm{cm})$, and two samples are from upper, massive divisions of carbonate turbidites (Samples 123-765C-19R-3, 63-66 cm, and 123765C-38R-3, 50-52 cm).

The five samples collected from the massive coarse basal divisions of carbonate turbidites are petrophysically similar. All have large throats, leptokurtic throat-size distributions, low-tomoderate recovery efficiency values, and concave cumulative-intrusion capillary-pressure curves (Fig. 1 and Plate 1, Figs. 1 through 3).

The two most-porous samples analyzed are both chalks having moderate throat sizes, platykurtic throat-size distributions, moderate recovery efficiency values, and gently sloping cumulativeintrusion capillary-pressure curves (Table 2; Samples 123-765C$35 \mathrm{R}-2,110-112 \mathrm{~cm}$, and 123-765C-19R-3, 63-66 cm). However, these two samples reached their current petrophysical condition in very different ways. Sample 123-765C-35R-2, 110-112 cm, is a coarse-textured bioclastic chalk, deposited near the base of a carbonate turbidite (Plate 1, Fig. 4; Plate 2, Figs. 1 and 2). This sediment was infiltrated by calcareous nannoplankton and other silt- and clay-size carbonate particles either during or shortly after deposition. The framework of coarse particles protected the finetextured matrix from compaction, preserving primary inter-

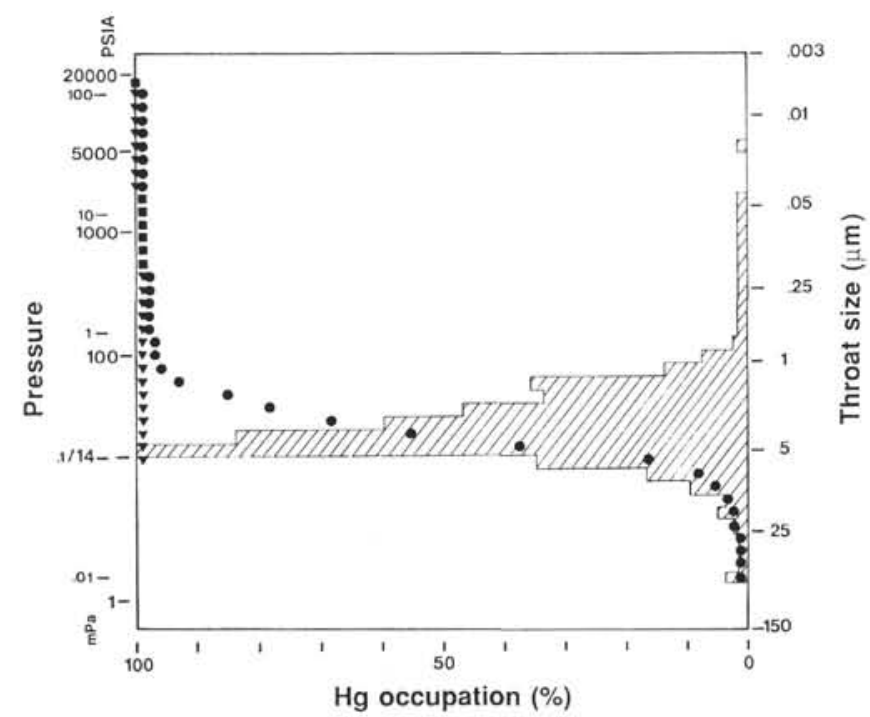

Figure 1. Capillary-pressure curve of Sample 123-765C-5R-1, $57 \mathrm{~cm}$. Solid dots = cumulative intrusion curve; solid triangles = cumulative extrusion curve; solid squares = overlapping cumulative intrusion and extrusion curves; hatched histogram $=$ incremental intrusion curve (Petrofacies I).
Table 2. Petrophysical data for all 22 samples analyzed.

\begin{tabular}{|l|l|l|l|l|l|}
\hline Site & $\begin{array}{c}\text { Depth } \\
\text { (mbsf) }\end{array}$ & Porosity & RE & MTS & Petrofacies \\
\hline 761 & 337.54 & 0.0775 & 0.3613 & 0.0490 & IV \\
761 & 338.48 & 0.1570 & 0.3800 & 0.0921 & IV \\
761 & 339.79 & 0.0858 & 0.3306 & 0.0735 & IV \\
761 & 347.51 & 0.1114 & 0.3539 & 0.0504 & IV \\
761 & 349.00 & 0.1049 & 0.4117 & 0.0460 & IV \\
761 & 369.61 & 0.1253 & 0.5581 & 0.0400 & IV \\
761 & 372.01 & 0.1031 & 0.4015 & 0.0481 & IV \\
761 & 375.55 & 0.1347 & 0.2580 & 0.1461 & IV \\
761 & 410.56 & 0.0247 & 0.1383 & 0.0263 & IV \\
761 & 419.53 & 0.1342 & 0.0918 & 0.7211 & III \\
761 & 420.45 & 0.1197 & 0.1163 & 0.4847 & I \\
\hline 765 & 389.17 & 0.1119 & 0.0088 & 4.0849 & I \\
765 & 410.54 & 0.1204 & 0.1857 & 0.2302 & I \\
765 & 431.08 & 0.1683 & 0.0156 & 0.5802 & I \\
765 & 459.63 & 0.1768 & 0.2010 & 5.2761 & I \\
765 & 524.94 & 0.2765 & 0.3139 & 0.2094 & II \\
765 & 676.70 & 0.3067 & 0.2052 & 0.2437 & II \\
765 & 685.02 & 0.1454 & 0.6289 & 0.0113 & IV \\
765 & 706.01 & 0.1229 & 0.3699 & 0.0378 & IV \\
765 & 715.28 & 0.1833 & 0.0261 & 0.2969 & I \\
\hline 766 & 399.14 & 0.1455 & 0.1521 & 0.0799 & III \\
766 & 407.17 & 0.1209 & 0.1845 & 0.0226 & III \\
\hline
\end{tabular}

MTS = median throat size. Porosity and RE measured as decimal fractions; MTS in micrometers.

particle and intraparticle porosity. Sample 123-765C-19R-3, 63$66 \mathrm{~cm}$, was deposited as a silt-size calcareous ooze in the upper division of a carbonate turbidite (Plate 2, Figs. 3 and 4). In this case, porosity was enhanced by dissolution of particles and by the occupation of large pore spaces by porous authigenic clay-mineral crystal aggregates. The growth of these clay minerals inhibited porosity destruction by calcium-carbonate cementation, preserved primary- and dissolution porosity, and generated intercrystalline microporosity within the clay aggregates. Comparison of these two samples highlights how diagenetic processes as well as depositional conditions may control pore-system evolution, and how different initial conditions and processes can yield similar results (in terms of capillary-pressure characteristics).

The remaining two samples of the nine collected from this site (123-765C-36R-2, 21-23 cm, and 123-765C-38R-3, 50-52 cm) are petrophysically similar. The first sample is from a silt-size laminated basal division of a turbidite, and the other sample is from a silt-size massive upper division of a turbidite. Both samples have small throats, leptokurtic throat-size distributions, high recovery efficiency values, and convex capillary-pressure curves (Fig. 2).

Two of the samples collected from Site 123 have very large throats (see Table 2). These are Samples 123-765C-5R-1, $57 \mathrm{~cm}$, and 123-765C-12R-3, 142-144 cm (see Fig. 1; Plate 1, Fig. 1, and Plate 3, Figs. 1 and 2). Both are middle Miocene chalks that form the basal portions of thin, coarse turbidites having little or no overlying fine material. These are the only two samples analyzed that were collected from turbidites that lacked or had very thin fine divisions (Bouma divisions B, C, D, or E; Bouma, 1962).

\section{Site 761, Triassic Neritic Carbonates}

Eleven samples of Triassic (Rhaetian and Norian) neritic carbonates were collected from Hole $761 \mathrm{C}$ (see Table 1). These samples were collected from lithologic Unit IV (basal portion) and from lithologic Unit V. Nine of these samples, consisting of skeletal mudstone, wackestone, and packstone, and one sample of oolitic and skeletal grainstone, form a petrophysically homoge- 


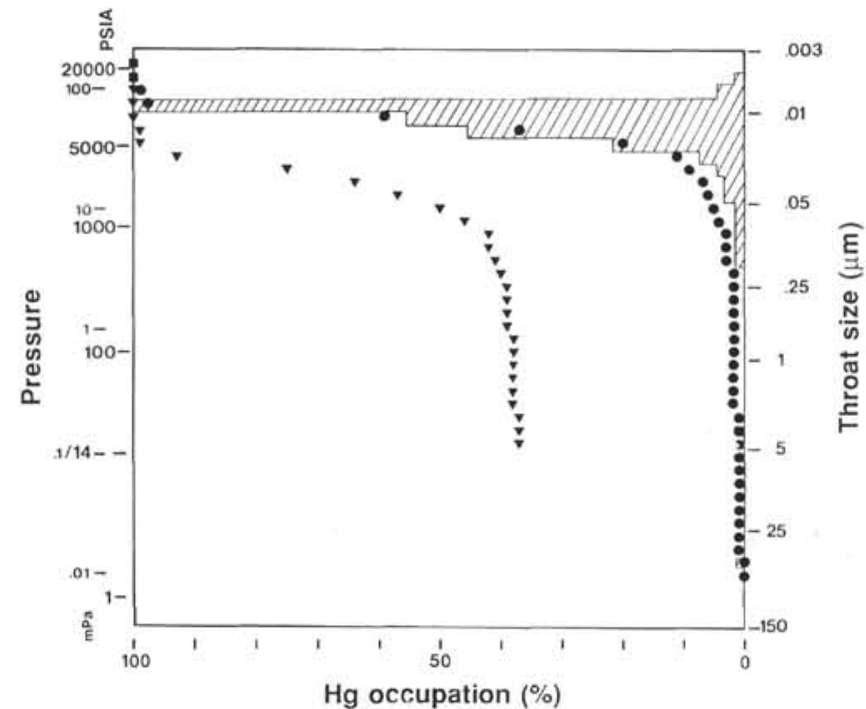

Figure 2. Capillary-pressure curve of Sample 123-765C-36R-2, 21-23 $\mathrm{cm}$. Notation as in Figure 1 (Petrofacies IV).

neous group. All are characterized by small throats, leptokurtic throat-size distributions, high recovery efficiency values, and convex cumulative-intrusion capillary-pressure curves (see Fig. 2 ). These rocks have been recrystallized to small (mostly $<10$ $\mu \mathrm{m}$ ) anhedral calcite crystals, or microspar (Plate 3, Figs. 3 and 4), which accounts for the uniformity of capillary-pressure characteristics among rocks of such disparate depositional fabrics.

Of the two remaining samples collected from this hole, one (Sample 122-761C-32R-2, 124-126 cm) was collected from the base of an event deposit. This sample has large throats, a leptokurtic throat-size distribution, a low recovery efficiency value, and a concave cumulative-intrusion capillary-pressure curve. The other sample (122-761C-32R-2, 32-34 cm), collected from the upper division of a different graded layer, has large throats, a platykurtic throat-size distribution, a low recovery efficiency value, and a gently sloping cumulative-intrusion capillary-pressure curve.

\section{Site 766, Lower Cretaceous Polymictic Sandstones}

The two samples collected from Hole 766A are sedimentologically and petrophysically similar. Both are Hauterivian polymictic sandstones collected from the basal divisions of turbidites in lithologic Subunit IIIB (Ludden, Gradstein, et al., 1990, fig. 10, p. 278), and both have small throats, polymodal throat-size distributions, moderate recovery efficiency values, and gently sloping cumulative-intrusion capillary-pressure curves (Fig. 3 and Plate 4, Figs. 1 and 2).

\section{DISCUSSION}

\section{Petrofacies Classification}

To interpret the origins and fluid-flow characteristics of rockpore systems, it is helpful to classify rocks petrophysically. A simple descriptive classification proposed by Kopaska-Merkel and Friedman (1989) is used here (Table 3). All 22 samples described here fall readily into four of the five petrofacies defined by Kopaska-Merkel and Friedman (see Table 2). This supports the generality of the classification, which was based initially on studies of deeply buried and dolomitized lower Paleozoic carbonates, the Hunton Group of Oklahoma and Texas, southwestern U.S.

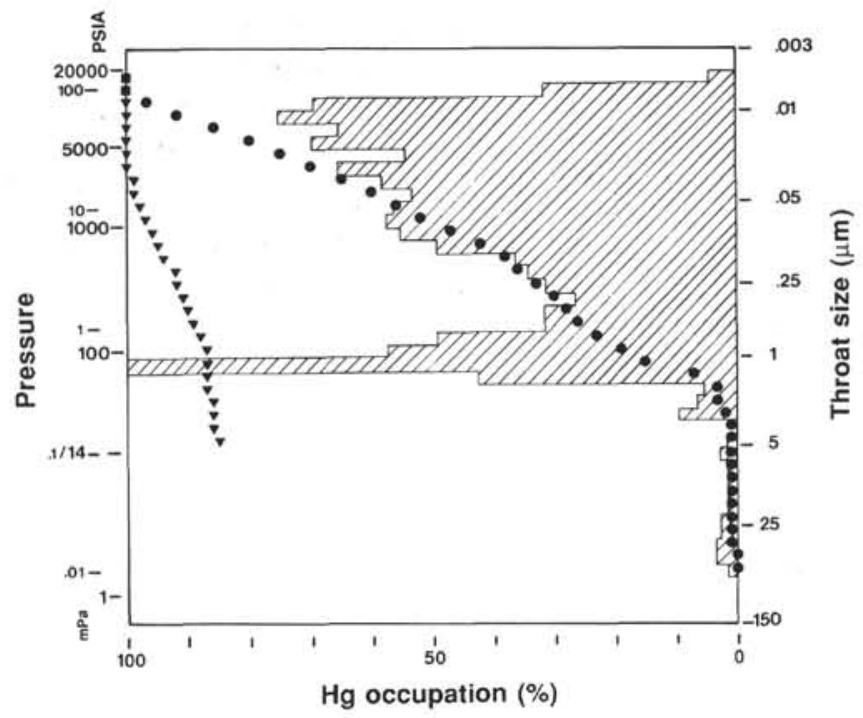

Figure 3. Capillary-pressure curve of Sample 123-766A-42R-4, 83-85 $\mathrm{cm}$. Notation as in Figure 1 (Petrofacies III).

The five samples of massive coarse turbidite bases from Hole $765 \mathrm{C}$ clearly belong to Petrofacies I, as does Sample 122-761C$32 \mathrm{R}-2,124-126 \mathrm{~cm}$, which also was collected from the coarse basal portion of an event deposit. These six samples share the following petrophysical characteristics: large throats (geometricmean median throat size $0.863 \mu \mathrm{m}$ ), leptokurtic throat-size distributions, low-to-moderate recovery efficiency values $(9.2 \%$ $\pm 8.8 \%$ ), concave cumulative-intrusion capillary-pressure curves, and high porosity values $(14.7 \% \pm 3.3 \%$ ) (see Fig. 1 ). In addition, these six samples all form the bases of relatively coarse-textured event deposits, at least five of which are turbidites (see Plate 1, Figs. 1 through 3 ). The petrophysical characteristics of these six samples most closely resemble those of vuggy dolostones assigned by Kopaska-Merkel and Friedman to Subpetrofacies IB. The large interparticle pores in the six samples from the Indian Ocean may play the same role for controlling fluid flow as do the abundant vugs and fossomolds in the Hunton-Group dolostones. Rocks assigned to Subpetrofacies IB are characterized by abundant large pores connected by homogeneous finer pore systems. This results in a tendency for nonwetting fluids to become trapped in the large pores when pressures are reduced, accounting for the low recovery efficiency values of these rocks. The trapping of nonwetting fluid in relatively large pores during pressure reduction is a result of disruption of the continuous nonwetting-fluid phase, a process called "snap-off" (Wardlaw and Taylor, 1976; Wardlaw et al., 1988; Amthor et al., 1988).

Two samples were assigned to Petrofacies II: 123-765C-35R-2, $110-112 \mathrm{~cm}$, and $123-765 \mathrm{C}-19 \mathrm{R}-3,63-66 \mathrm{~cm}$. These two samples share the following petrophysical characteristics: moderate throat sizes (geometric-mean median throat size $0.226 \mu \mathrm{m}$ ), platykurtic throat-size distributions, moderate-to-high recovery efficiency values $(26.0 \% \pm 7.7 \%)$, gently sloping cumulative-intrusion capillary-pressure curves, and very high porosity values $(27.6 \%$ to $30.7 \%$ ) (Fig. 4). These two samples are dissimilar in both depositional and diagenetic fabrics. Sample 123-765C-35R-2, 110 $112 \mathrm{~cm}$, is a coarse-textured bioclastic chalk with infiltrated fines (see Plate 1, Fig. 4, and Plate 2, Figs. 1 and 2), whereas the other sample is a silt-size calcareous chalk that has undergone extensive dissolution of calcium-carbonate particles and growth of authigenic clays (see Plate 2, Figs. 3 and 4). The Paleozoic carbonates that Kopaska-Merkel and Friedman assigned to this petrofacies 
Table 3. Petrofacies classification applied to Indian-Ocean carbonates (after Kopaska-Merkel and Friedman, 1989).

\begin{tabular}{|c|c|c|c|c|c|}
\hline Petrofacies & Porosity & $\begin{array}{l}\text { Cumulative } \\
\text { CP curve }\end{array}$ & $\begin{array}{l}\text { Throat-size } \\
\text { distribution }\end{array}$ & $\mathrm{RE}$ & MTS \\
\hline 1 & High & Dominantly concave & Leptokurtic & Moderate & Large \\
\hline ॥ & Moderate & Sloping or bimodal & Platykurtic or polymodal & High & Moderate \\
\hline III & Moderate & Bimodal & Platykurtic or polymodal & Low & Small \\
\hline IV & Low & Convex & Leptokurtic & High & Small \\
\hline V & Very low & Convex & Leptokurtic & Low & Small \\
\hline
\end{tabular}

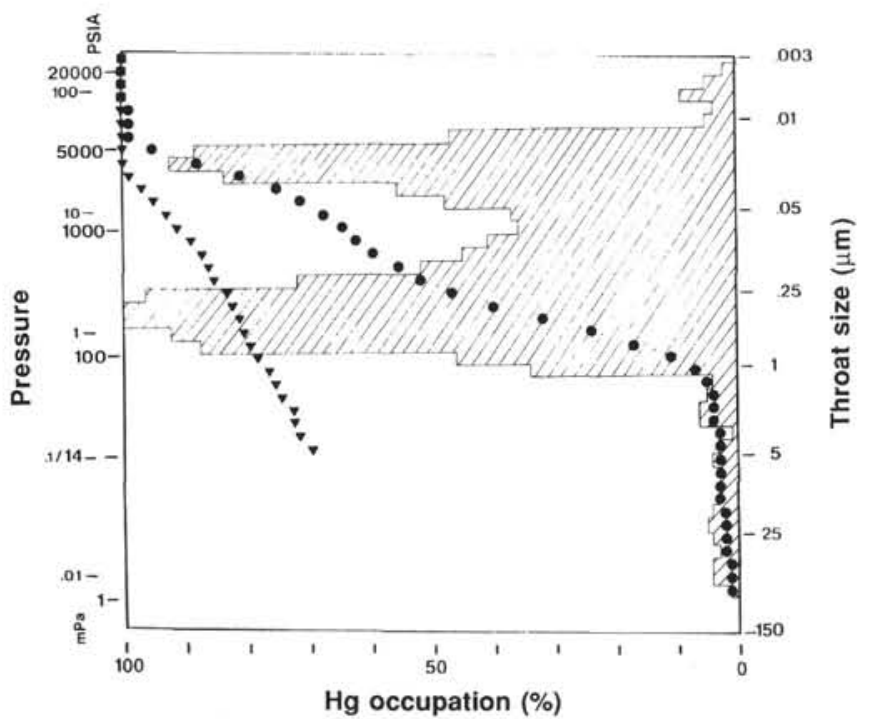

Figure 4. Capillary-pressure curve of Sample 123-765C-19R-3, 63-66 $\mathrm{cm}$. Notation as in Figure 1 (Petrofacies II).

have pore systems that probably more closely resemble that of Sample 123-765C-35R-2, 110-112 cm, because the Paleozoic rocks are skeletal wackestone, packstone, and grainstone.

Three samples have been assigned to Petrofacies III; these are the two polymictic sandstones from Hole 766A (see Plate 4) and a skeletal packstone from Hole $761 \mathrm{C}$. These samples are characterized by small throats (geometric-mean median throat size 0.109 $\mu \mathrm{m})$, polymodal throat-size distributions, moderate recovery efficiency values $(14.3 \% \pm 4.7 \%)$, gently sloping cumulative-intrusion capillary-pressure curves, and high porosity values $(13.4 \%$ $\pm 1.2 \%$ ) (see Fig. 3 ). The two siliciclastic-rich samples from Hole $766 \mathrm{~A}$ have higher recovery efficiency values than either the sample from Hole 761C or the Paleozoic dolomitized oomoldic ooid grainstones that Kopaska-Merkel and Friedman assigned to this petrofacies. This difference may be insignificant, or may result from a fundamental difference between carbonate-dominated- and siliciclastic-dominated pore systems. The most striking features uniting these sedimentologically disparate sets of samples in Petrofacies III are their polymodal pore systems. However, the polymodality is achieved in very different ways. The Paleozoic carbonates of the Hunton Group have a combination of coarse particle-moldic porosity and fine intercrystalline microporosity. By contrast, the polymictic sandstones from Hole $766 \mathrm{~A}$ have complex pore systems resulting from (1) a poorly sorted coarse-textured depositional fabric and (2) several different scales of microporosity within altered particles. The nature of the pore system in the sample from Hole $761 \mathrm{C}$ is unknown.
Eleven samples were assigned to Petrofacies IV. Nine of these samples are recrystallized neritic carbonates (from Hole 761C), which had diverse depositional fabrics but which now have similar pore systems dominated by secondary intercrystalline pores (see Plate 3, Figs. 3 and 4). These rocks have small throats (geometric-mean median throat size $0.047 \mu \mathrm{m}$ ), leptokurtic throat-size distributions, high recovery efficiency values $(38.1 \%$ $\pm 13.1 \%$ ), convex cumulative-intrusion capillary-pressure curves, and relatively low porosity values $(10.8 \% \pm 3.7 \%)$ (see Fig. 2). Two other samples were assigned to this petrofacies; both are Aptian chalks from Hole $765 \mathrm{C}$ that were collected from turbidites, but not from coarse-textured massive units. The pore systems of these two chalks are dominated by small primary interparticle pores. These two sets of rock samples are petrophysically similar, but differ in depositional fabrics and diagenetic histories. The data set used by Kopaska-Merkel and Friedman to establish this petrofacies also consisted of two dissimilar rock types (tightly cemented ooid grainstones and chert plus cherty carbonates) both of which were sedimentologically unlike the Indian-Ocean carbonates assigned to this petrofacies. The pore systems of the tightly cemented ooid grainstones have been considerably altered by interparticle calcium-carbonate cementation, whereas those of the cherty rocks have been altered by replacive growth of silica. Both of these rock types are unlike either set of Indian-Ocean samples assigned to this petrofacies. It may be that the kind of pore system characteristic of Petrofacies IV may be created in many different ways. This pore system also seems to be one of the more common kinds of pore systems that are produced by diagenesis (19 of 84 samples studied by Kopaska-Merkel and Friedman [1989] and 11 of 22 samples described here). In addition, for both data sets, Petrofacies IV is characterized by relatively low porosity values. Petrofacies IV is where many onceporous and -permeable rocks go when their capacity to store substantial amounts of fluid has been destroyed.

No samples described here were assigned to Petrofacies V.

\section{Pore-System Evolution}

The evolution of pore systems described here was straightforward. Samples from Hole $761 \mathrm{C}$ are highly altered neritic carbonates whose pore-system characteristics have been almost entirely controlled by diagenesis. The dominant pores are intercrystalline pores between neomorphic calcite crystals, and the distribution of these pores has been little affected by primary depositional fabric. By contrast, most samples from Holes $765 \mathrm{C}$ and $766 \mathrm{~A}$ have been only slightly altered, and their pore systems have been strongly affected by depositional conditions. Pore systems of carbonate turbidites from Hole $765 \mathrm{C}$ are dominated by interparticle porosity, although several samples show significant pore-system modifications (e.g., Sample 123-765C-19R-3, 63-66 cm). These modifications were caused by (1) infiltration of fine sediment into underlying coarser sediment, (2) dissolution of unstable particles to create secondary porosity, and/or (3) growth of authigenic clay 
minerals, which occluded some preexisting pores, created new intercrystalline pores, and blocked or partially blocked some pore throats with clay-mineral fans and rosettes.

The two samples having anomalously large throats also are the only two samples from very thin (8-cm-thick), coarse-textured turbidites that lack or have poorly developed upper (fine) divisions. The large interparticle pores of the coarse-textured chalks with their large throats were apparently protected from clogging with clay- and silt-size matrix, because little fine sediment was deposited with and overlying the coarse basal layers (see Plate 1, Fig. 1 and Plate 3, Figs. 1 and 2). By contrast, Sample 123-765C$35 \mathrm{R}-2,110-112 \mathrm{~cm}$, a coarse-textured chalk forming the base of a turbidite that includes a thick, fine-textured upper division, had its throat size substantially reduced by syndepositional or postdepositional clogging of large interparticle pores by calcareous nannofossils and other silt- and clay-size material (see Plate 1, Fig. 4 and Plate 2, Figs. 1 and 2). It may be that the high permeability values of the coarse basal divisions of turbidites were most likely to be preserved in turbidites that lacked significant fine divisions.

\section{Prediction of Petrophysical Parameters}

For the samples from Hole 761C, prediction of petrophysical parameters will be most successful if based on analysis of diagenetic-facies patterns. Depositional lithofacies patterns have exercised little control on petrofacies distribution in these rocks. By contrast, less highly altered rocks collected from Sites 765 and 766 retain a significant depositional-fabric imprint on pore-system characteristics. This is illustrated by the distinct differences in petrophysical characteristics between samples from coarse turbidite bases and those from the upper, finer, portions of turbidites, at Site 765 (Fig. 5). Therefore, prediction of the distribution of favorable reservoir facies or of permeability barriers in these rocks, for the purpose of hydrocarbon exploration, aquifer development, or studies of regional subsurface fluid-flow patterns, should be based on depositional patterns.
The small number of samples analyzed, and their biased distribution with respect to depositional lithofacies in Holes $765 \mathrm{C}$ and $766 \mathrm{~A}$, prevents development of a predictive numerical model of reservoir quality. However, the data presented here, indicating strong correlations between depositional facies and petrophysical characteristics, demonstrate that such a model might readily be formulated if sufficient data were available. The following factors should be among those considered for inclusion in such a model: porosity, permeability, recovery efficiency, throat size (central tendencies, standard deviations, and maxima), thickness of petrophysically homogeneous strata, dominant pore and throat types, and depositional lithofacies.

As mentioned above, by far the largest pore throats observed here occur in thin coarse turbidites that lack, or have poorly developed, upper (fine) divisions. The ability to predict the distribution of such turbidites would aid in petroleum exploration. Abundant, relatively coarse turbidites that lack fine divisions suggest deposition on channeled suprafan lobes on the proximal portions of channeled mid-fan areas of submarine fans (see, e.g., Walker, 1984). However, carbonate-dominated fans may have different facies patterns than siliciclastic fans. In addition, no submarine-fan models yet exist that can precisely predict the distribution of units as small as those described here.

The two samples in question come from lithologic Subunit IIB (middle Miocene) in Hole $765 \mathrm{C}$ from a major submarine-fan system that persisted from the Oligocene to the present day, but reached its peak at Site 765 during the late Miocene. The interval containing the two samples of "truncated" coarse turbidites (roughly $350-460 \mathrm{mbsf}$ ) has been interpreted as a progradational sequence of mid- to outer-fan sediments, on the basis of verticalsequence analysis (Ludden, Gradstein, et al., 1990). This is consistent with the more specific setting proposed above for the two samples, based on facies models summarized by Walker (1984). Evidence for channeling observed in sediments of lithologic Subunit IIB consists of abundant scoured basal contacts of turbidites (Ludden, Gradstein, et al., 1990; barrel sheets).

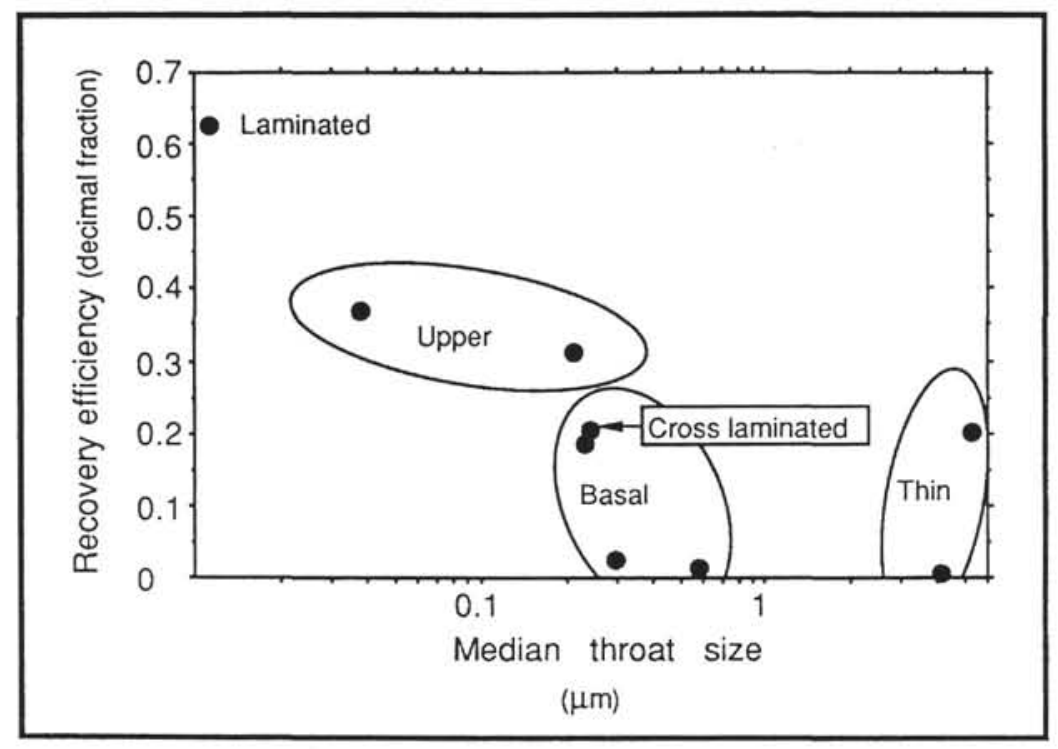

Figure 5. Bivariate graph of RE vs. median throat size (MTS) for nine samples collected from turbidites in Hole 765C. Sedimentary facies from the Bouma sequence form discrete clusters of points on this graph. For example, the two samples from thin coarse turbidites that were dominated by the "A" divisions plot together at high MTS and low RE. The two samples from upper massive divisions have intermediate values of both variables, whereas the single sample from a silt-size laminated turbidite base plots near the upper left corner of the graph. 
Markov chain analysis indicates that an important component of turbidites consists of couplets of sand-size massive carbonate overlain by fine massive carbonate in the middle and upper portions of lithologic Subunit IIB (Ludden, Gradstein, et al., 1990). These turbidites are thin, and the upper fine divisions commonly form a lesser percentage of total turbidite thickness than do those of turbidites from other stratigraphic intervals at Site 765 . These thin turbidites therefore resemble sedimentologically the two thin turbidites that were sampled for this study and probably have similar pore systems. This inference is supported by anomalously high porosity values recorded from this interval (Ludden, Gradstein, et al., 1990, fig. 86, p. 175). This interval is also characterized by greater lithification of sediments composing carbonate turbidites (but not of intercalated pelagic clays) relative to overlying and underlying intervals, with resultant high-amplitude variations in velocity, density, and acoustic impedance. This interval corresponds to a series of high-amplitude seismic reflections observed in the vicinity of Site 765 (Ludden, Gradstein, et al., 1990). This suggests that seismic data might provide an additional method of exploring for high-porosity, high-permeability, thin turbidites that contain little or no fine material.

Recovery efficiency (RE) is inversely related to both porosity and median throat size for the samples described here (Fig. 6). Amthor et al. (1988) found a similar relationship for lower Paleozoic carbonates of the Hunton Group in Oklahoma and Texas, and the Ordovician Ellenburger Formation in Texas and New Mexico, as did Krause et al. (1987) for a set of 28 samples of medium- to thick-bedded sandstone. By contrast, Wardlaw $(1976,1980)$ reported positive relationships between porosity and RE for Devonian dolostones and for 92 carbonate-rock samples, respectively. Why opposing relationships of these variables occur in data collected from different sets of carbonate-rock samples is unknown.

Interestingly, all previously published capillary-pressure data for sedimentary rocks show a maximum RE of $60 \%$, whereas the maximum for the Indian-Ocean samples described here is slightly higher, nearly $63 \%$. This higher maximum RE value may result from the lesser age, and presumably less-intense diagenesis, of the Indian-Ocean samples relative to Paleozoic carbonates. Most likely, Indian-Ocean carbonate rocks with unusually high RE values have some combination of low pore/throat size ratios, small throat lengths and low tortuosities, smooth throat walls, and homogeneity of pore-systems on centimeter and subcentimeter scales (e.g., Wardlaw and Taylor, 1976; Wardlaw et al., 1988).

\section{SUMMARY}

The Mesozoic carbonates from the Argo Abyssal Plain (Hole $765 \mathrm{C}$ ) and the Wombat Plateau (Hole 761C), the Tertiary carbonates from the Argo Abyssal Plain (Hole 765C), and the Hauterivian sandstones from the Gascoyne Abyssal Plain (Hole 766A) have been satisfactorily classified petrophysically using the classification developed for lower Paleozoic carbonates of the Hunton Group by Kopaska-Merkel and Friedman (1989). The main difference between the two data sets is that most of the Indian-Ocean rocks are substantially more porous than petrophysically equivalent Hunton rocks.

Petrofacies assignments for the Indian-Ocean samples are as follows. Petrofacies I includes six samples collected from the coarse basal portions of event deposits (primarily turbidites). These samples have large throats, leptokurtic throat-size distributions, low-to-moderate recovery efficiency values, concave cumulative-intrusion capillary-pressure curves, and high porosity values. Petrofacies II includes two sedimentologically dissimilar samples that have medium-size throats, platykurtic throat-size distributions, moderate-to-high recovery efficiency values, gently sloping cumulative-intrusion capillary-pressure curves, and high porosity values. Petrofacies III includes two polymictic sandstones and a skeletal packstone that have small throats, polymodal throat-size distributions, moderate recovery efficiency values, gently sloping cumulative-intrusion capillary-pressure curves, and high porosity values. Petrofacies IV includes 11 samples, mostly recrystallized neritic carbonates, that have small throats, leptokurtic throat-size distributions, high recovery efficiency values, convex cumulative-intrusion capillary-pressure curves, and low porosity values.

For Hole 761C, prediction of petrophysical parameters should be most successful if based on diagenetic-facies patterns. Depositional facies exercised little control on petrofacies distribution in these rocks. By contrast, less highly altered rocks collected

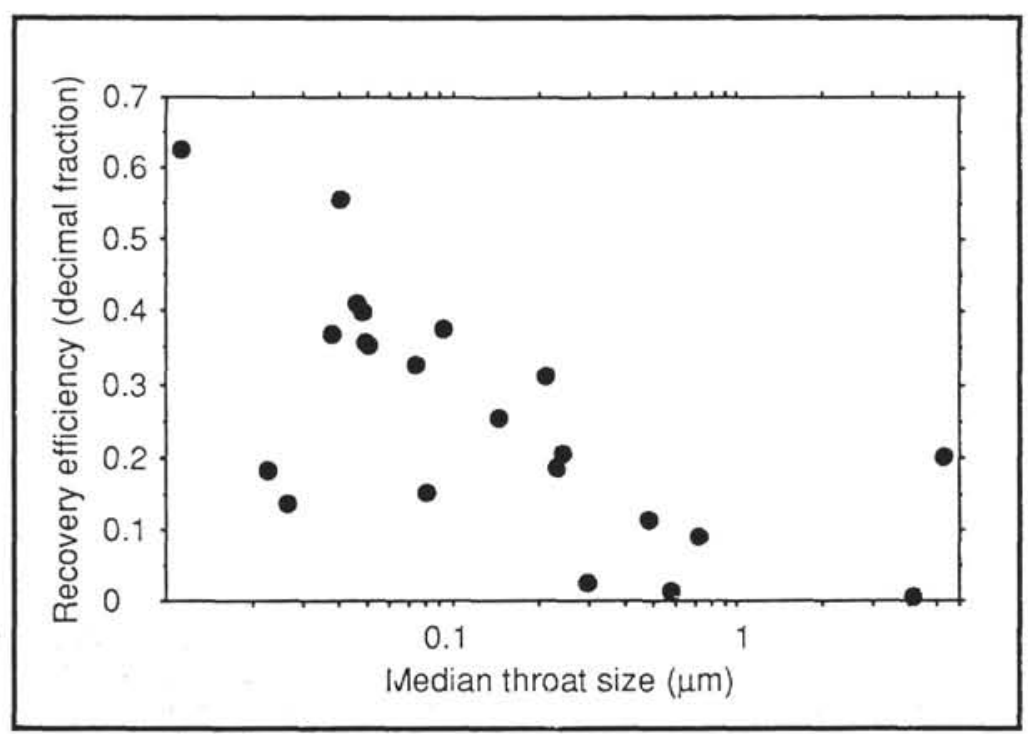

Figure 6. Bivariate graph of RE vs. MTS for all 22 samples. Inverse relationship between maximum RE and MTS is similar to that observed in some sedimentary-rock data sets and different from that observed in others. See text for discussion. 
from Holes $765 \mathrm{C}$ and $766 \mathrm{~A}$ retain a significant imprint of the depositional fabrics on pore-system characteristics. Therefore, prediction of the distribution of favorable reservoir facies or of permeability barriers in these rocks, for the purpose of hydrocarbon exploration, aquifer development, or studies of regional subsurface fluid-flow patterns, should be based on depositional patterns.

The small number of samples analyzed, and their biased distribution with respect to depositional lithofacies, prevents development of predictive numerical models of reservoir quality for Indian-Ocean carbonates. However, such a model could readily be formulated if sufficient data were collected. The following factors should be considered for inclusion in such a model: porosity, permeability, recovery efficiency, throat size (central tendencies, standard deviations, and maxima), thickness of petrophysically homogeneous strata, dominant pore and throat types, and depositional lithofacies. RE is inversely related to both porosity and median throat size for the Indian-Ocean samples. Previously published studies of capillary-pressure characteristics of carbonate rocks show both inverse and positive relationships between $\mathrm{RE}$ and porosity and median throat size.

The coarse deposits of the massive basal units of turbidites are petrophysically distinct and form a coherent petrophysical group (Petrofacies I) having substantial reservoir potential. Two samples assigned to Petrofacies I have extremely large throats (median throat size at least $4 \mu \mathrm{m}$ and at least six times that of any other sample) and therefore high permeability values. These two samples come from thin, coarse turbidites that lack or have poorly developed fine divisions and are interpreted to have been deposited on channeled suprafan lobes in a proximal mid-fan setting. The restriction of extremely high permeability values to a single depositional facies suggests that careful facies mapping of deepsea fans in a deliberate search for such coarse turbidites might dramatically enhance success of exploration for aquifers or for hydrocarbon reservoirs. Such reservoirs would have high lateral permeability values but low vertical permeability values, and reservoir sections would include numerous thin units having widely differing petrophysical characteristics.

\section{ACKNOWLEDGMENTS}

This research was supported by a USSAC research grant awarded to the author while at the Northeastern Science Foundation. Tom Hare of Adirondack Environmental Services operated the SEM and took the photographs. An earlier version of this paper was reviewed by Robert Ehrlich and Jerry Lucia.

\section{REFERENCES}

Amthor, J. E., Kopaska-Merkel, D. C., and Friedman, G. M., 1988. Reservoir characterization, porosity, and recovery efficiency of deeply buried Paleozoic carbonates: examples from Oklahoma, Texas and New Mexico. Carbonates and Evaporites, 3:33-52.

Bouma, A. H., 1962. Sedimentology of Some Flysch Deposits. A Graphic Approach to Facies Interpretation: Amsterdam (Elsevier Publ. Co.).

Choquette, P. W., and Pray, L. C., 1970. Geological nomenclature and classification of porosity in sedimentary carbonates. AAPG Bull., 54:207-250.

Dullien, F.A.L., 1979. Porous Media: Fluid Transport and Pore Structure: Orlando, FL (Academic Press).

Dullien, F.A.L., and Dhawan, G. K., 1974. Characterization of pore structure by a combination of quantitative photomicrography and mercury porosimetry. J. Colloid Interface Sci., 47:337-349.

Ghosh, S. K., and Friedman, G. M., 1989. Petrophysics of a dolostone reservoir: San Andres Formation (Permian), west Texas. Carbonates and Evaporites, 4:45-119.
Ghosh, S. K., Urschel, S. F., and Friedman, G. M., 1987. Substitution of simulated well-cuttings (sic) for core plugs in the petrophysical analysis of dolostones: Permian San Andres Formation, Texas. Carbonates and Evaporites, 2:95-100.

Good, R. J., and Mikhail, R. S., 1981. The contact angle in mercury intrusion porosimetry. Powder Technol., 29:53-62.

Jennings, J. B., 1987. Capillary pressure (sic) techniques: application to exploration and development geology. AAPG Bull., 71:1196-1209.

Kopaska-Merkel, D. C., 1988, New applications in the study of porous media: determinations of pore-system characteristics on small fragments (Part I). Northeastern Environ. Sci., 7:127-142.

1991. Analytical procedure and experimental design for geological analysis of reservoir heterogeneity using mercury porosimetry, Geol. Surv. Alabama Circ., 153.

Kopaska-Merkel, D. C., and Amthor, J. E., 1988. Reservoir characterization with very high-pressure porosimetry. Carbonates and Evaporites, 3:53-63.

Kopaska-Merkel, D. C., Amthor, J. E., and Friedman, G. M., 1987. Notes on the Use of a Mercury Porosimeter (Micromeritics Pore Sizer 9305): Troy, NY (Northeastern Sci. Found.), Tech. Rept. No. 1.

Kopaska-Merkel, D. C., and Friedman, G. M., 1989. Petrofacies analysis of carbonate rocks: example from lower Paleozoic Hunton Group of Oklahoma and Texas. AAPG Bull., 73:1289-1306.

Krause, F. F., Collins, H. N., Nelson, D. A., Machemer, S. D., and French, P. R., 1987. Multiscale anatomy of a reservoir: Geological characterization of Pembina-Cardium Pool, west-central Alberta, Canada. AAPG Bull., 71:1233-1260.

Larson, R. G., and Morrow, N. R., 1981. Effects of sample size on capillary pressures in porous media. Powder Technol., 30:123-138.

Leg 123 Shipboard Scientific Party, 1988. Sedimentology of the Argo and Gascoyne abyssal plains, NW Australia: report on Ocean Drilling Program Leg 123 (Sept. 1-Nov. 1, 1988). Carbonates and Evaporites, $3: 201-212$

Levorsen, A. L., 1967. Geology of Petroleum, 2nd Ed.: San Francisco (Freeman Press).

Ludden, J. N., Gradstein, F. M., et al., 1990. Proc. ODP, Init. Repts., 123: College Station, TX (Ocean Drilling Program).

Micromeritics Instrument Corp., 1983. Instrument Manual, Pore Sizer 9305. 1 Micromeritics Dr., Norcross, GA 30093, U.S.A.

Purcell, W. R., 1949. Capillary-pressures-their measurement using mercury and the calculation of permeability therefrom. Trans. Soc. Pet. Engrs., AIME, 186:39-48.

Schowalter, T. T., 1979. Mechanisms of secondary hydrocarbon migration and entrapment. AAPG Bull., 63:723-760.

Smith, D. A., 1966. Theoretical considerations of sealing and nonsealing faults. AAPG Bull., 50:363-374.

Van Brakel, J., Modry, S., and Svata, M., 1981. Mercury porosimetry: the state of the art. Powder Technol., 29:1-12.

von Rad, U., Thurow, J., Haq, B. U., Gradstein, F. M., Ludden, J., and Legs 122 and 123 Shipboard Scientific Parties, 1989. Triassic to Cenozoic evolution of the NW Australian continental margin and the birth of the Indian Ocean (preliminary results of ODP Legs 122 and 123). Geologische Rundschau, 78:1189-1210.

Walker, R. G., 1984. Turbidites and associated coarse clastic deposits. In Walker, R. G. (Ed.), Facies Models, 2nd Ed. Geosci. Can. Reprint Ser., $1: 171-188$.

Wardlaw, N. C., 1976. Pore geometry of carbonate rocks as revealed by pore casts and capillary pressure. AAPG Bull., 60:245-257.

1980. The effects of pore structure on displacement efficiency in reservoir rocks and in glass micromodels. Soc. Pet. Engrs. AIME, Preprint SPE 8843:345-352.

Wardlaw, N. C., and McKellar, M., 1981. Mercury porosimetry and the interpretation of pore geometry in sedimentary rocks and artificial models. Powder Technol., 29:127-143.

Wardlaw, N. C., and Taylor, R. P., 1976. Mercury capillary pressure (sic) curves and the interpretation of pore structure and capillary behavior in reservoir rocks. Can. Pet. Geol. Bull., 24:225-262.

Wardlaw, N. C., McKellar, M., and Yu, Li, 1988. Pore and throat size distribution determined by mercury porosimetry and by direct observation. Carbonates and Evaporites, 3:1-15. 
Yu, Li, and Wardlaw, N. C., 1986a. The influence of wettability and critical pore-throat size ratio on snap-off. J. Colloid Interface Sci. 109:461-472.

1986b. Mechanisms of nonwetting phase (sic) trapping during imbibition at slow rates. J. Colloid Interface Sci., 109:473-486.

Yu, Li, Laidlaw, W. G., and Wardlaw, N. C., 1986. Sensitivity of drainage and imbibition to pore structures as revealed by computer simulation of displacement process. Adv. Colloid Interface Sci., 26:1-68.

Date of initial receipt: 19 May 1990

Date of acceptance: 30 October 1990

Ms 123B-145

\section{APPENDIX}

\section{Definitions of Terms}

Effective porosity: Porosity calculated from mercury-porosimetry data ([pore volume/bulk volume] $\times 100$ ). If $\log$ porosity is also discussed, a clear distinction should always be made between the two, because they are not identical. Use of this term is especially troublesome because it can mean so many different things. In mercury porosimetry, effective porosity commonly means porosity intruded by mercury at some standard pressure.

Petrofacies: A facies defined primarily or exclusively on petrophysical criteria.

Pore-throat-size distribution: The porosimeter measures the total relative volume (actually electrical capacitance converted to volume) of the pore system intruded at each of a series of pressures. Each pressure is interpreted to correspond to a particular throat size and to all pores accessed through throats of that size.

Recovery efficiency $(R E)$ : RE is the percentage of trapped hydrocarbons that may be withdrawn from a reservoir rock under a particular set of conditions. With respect to experiments in mercury porosimetry, this definition is modified slightly. RE in mercury porosimetry is the percentage or fraction of mercury (intruded at maximum pressure) that is extruded during pressure reduction to final minimum pressure (usually $14-15$ psia [0.09-0.1 MPa], or atmospheric pressure). 


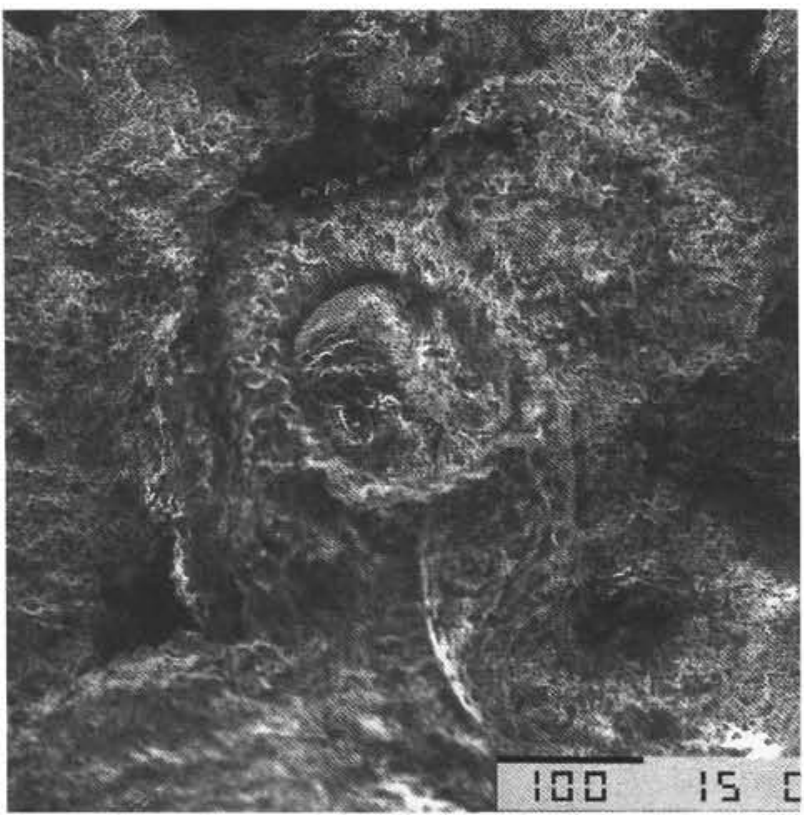

1

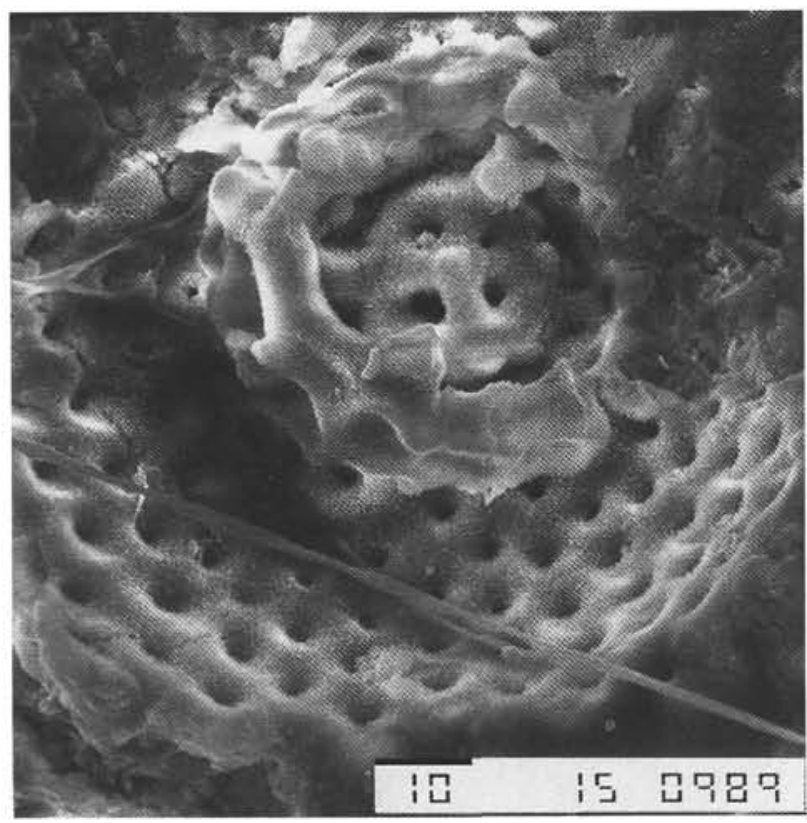

3

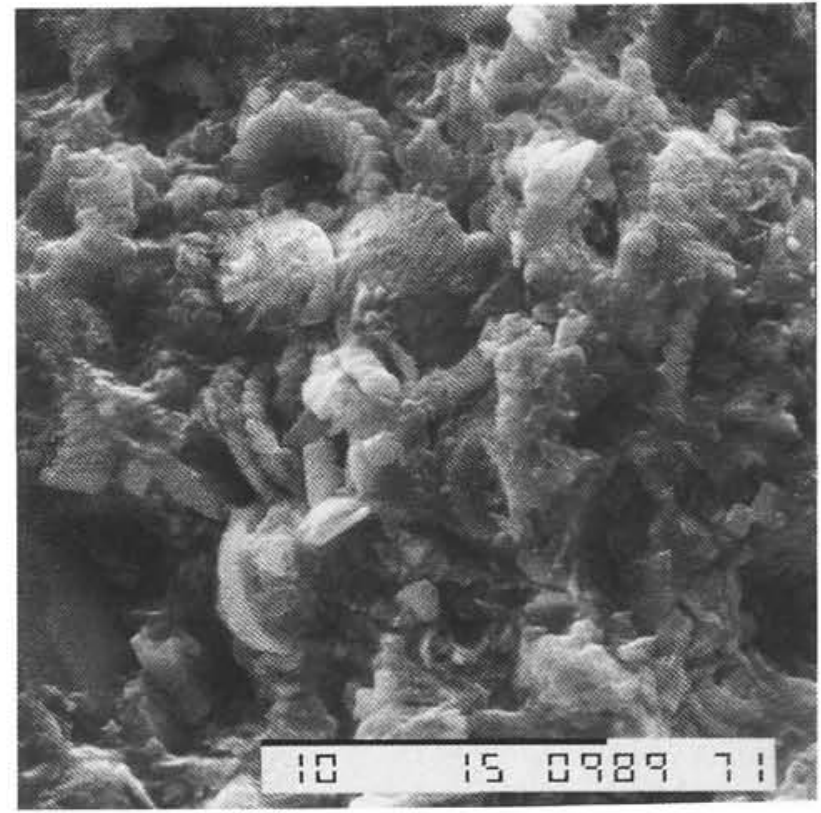

2

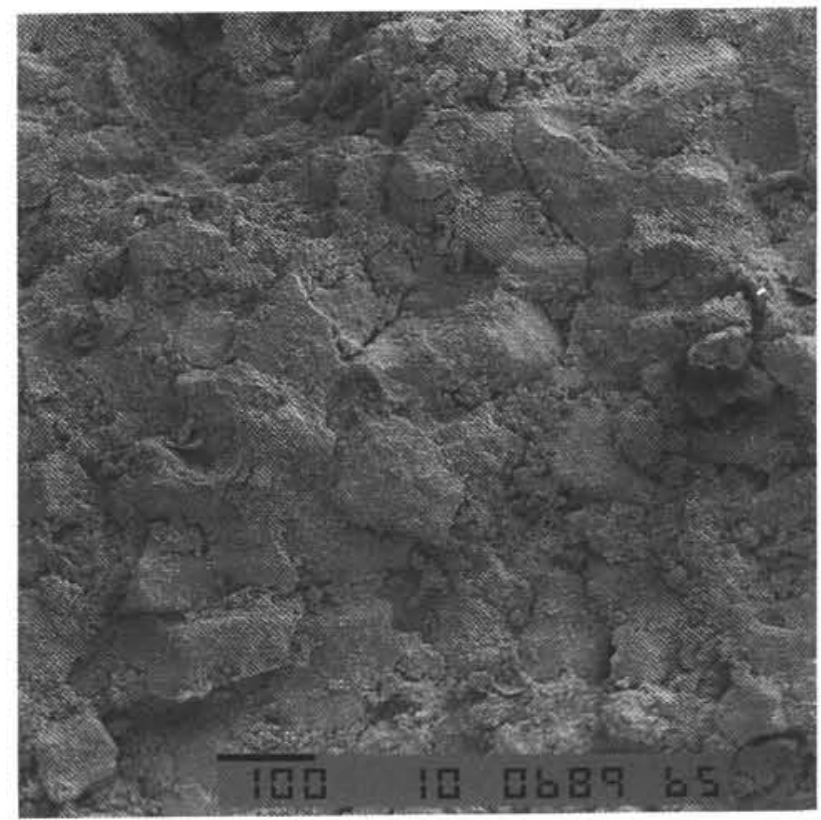

4

Plate 1. SEM photomicrographs; scales in micrometers. 1. Sample $123-765 \mathrm{C}-5 \mathrm{R}-1,57 \mathrm{~cm}$. Planktonic foraminifers in foraminiferal chalk, with interparticle porosity. 2. Sample 123-765C-39R-3, $57-59 \mathrm{~cm}$. Substantial primary porosity among calcareous nannofossils in calcareous chalk. 3. Sample $123-765 \mathrm{C}-39 \mathrm{R}-3,57-59 \mathrm{~cm}$. Radiolarian in calcareous chalk. Fiber stuck to sample after collection. 4 . Sample 123-765C-35R-2, 110-112 cm. Porous and coarse-textured calcareous chalk. 


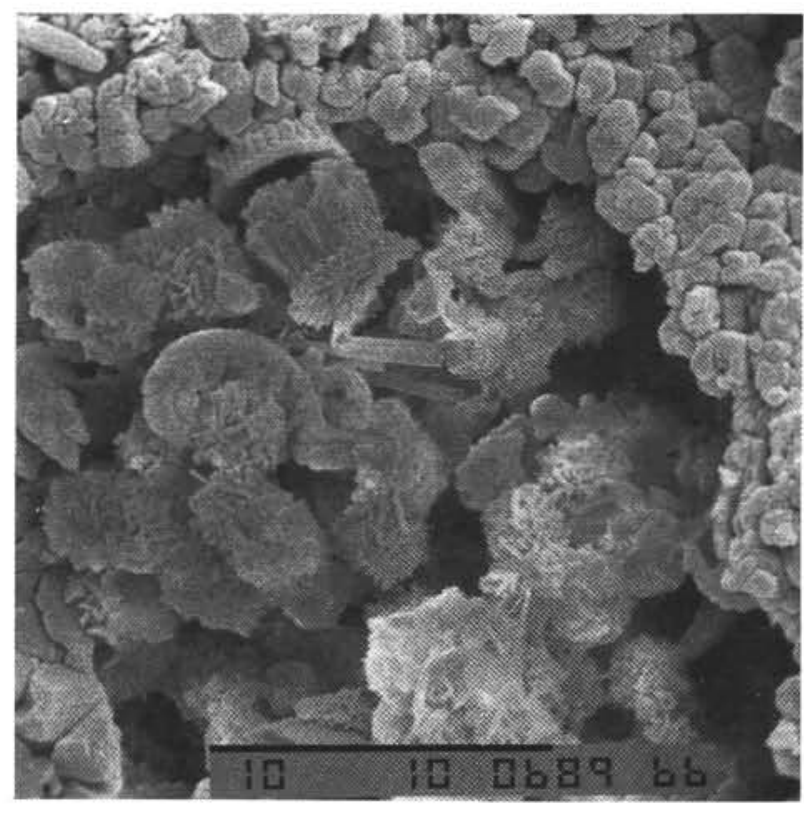

1

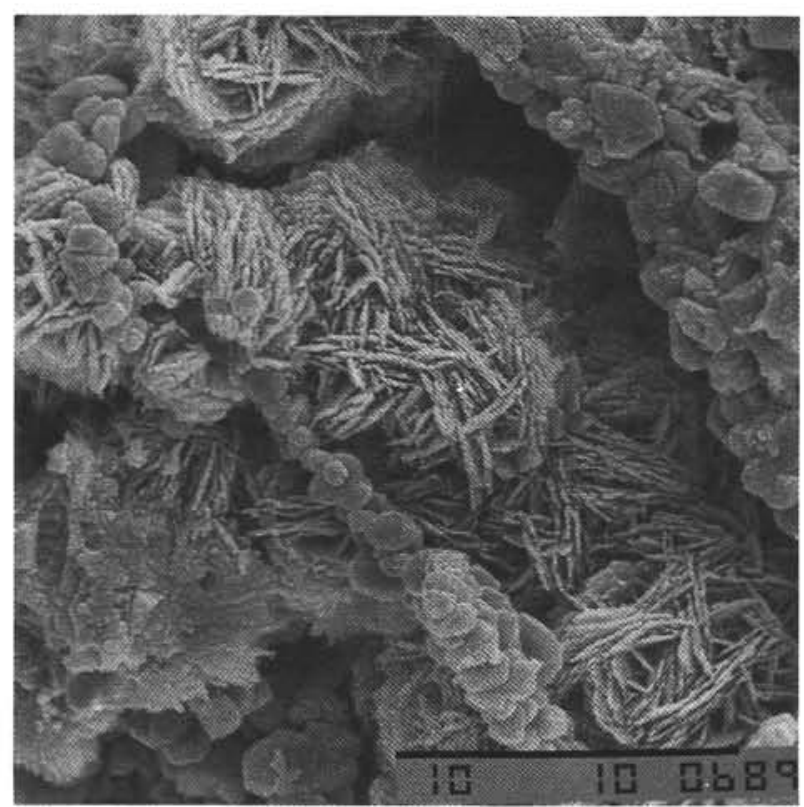

3

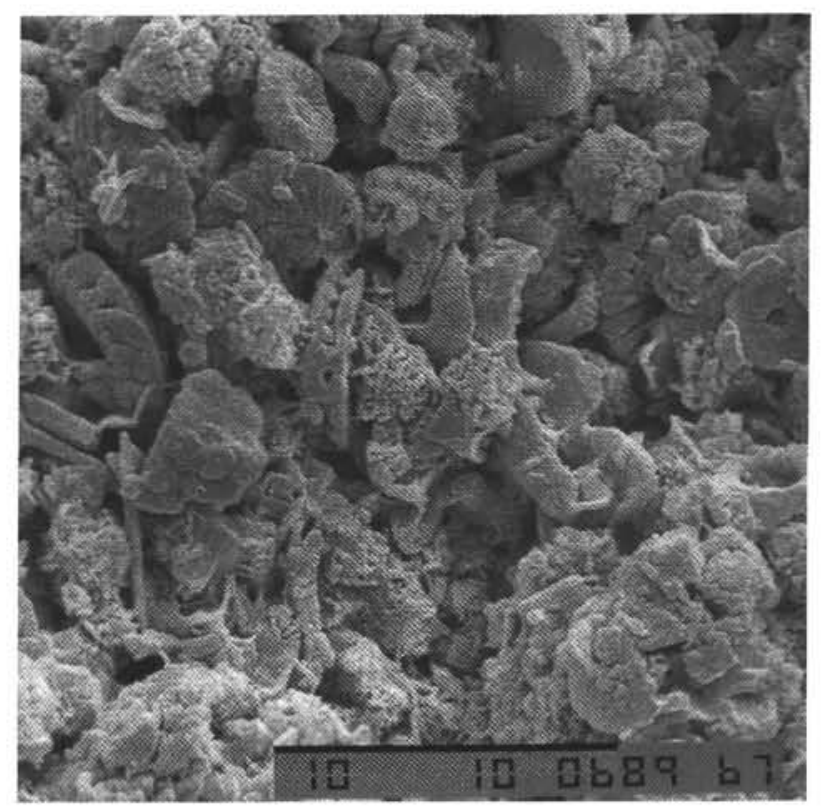

2

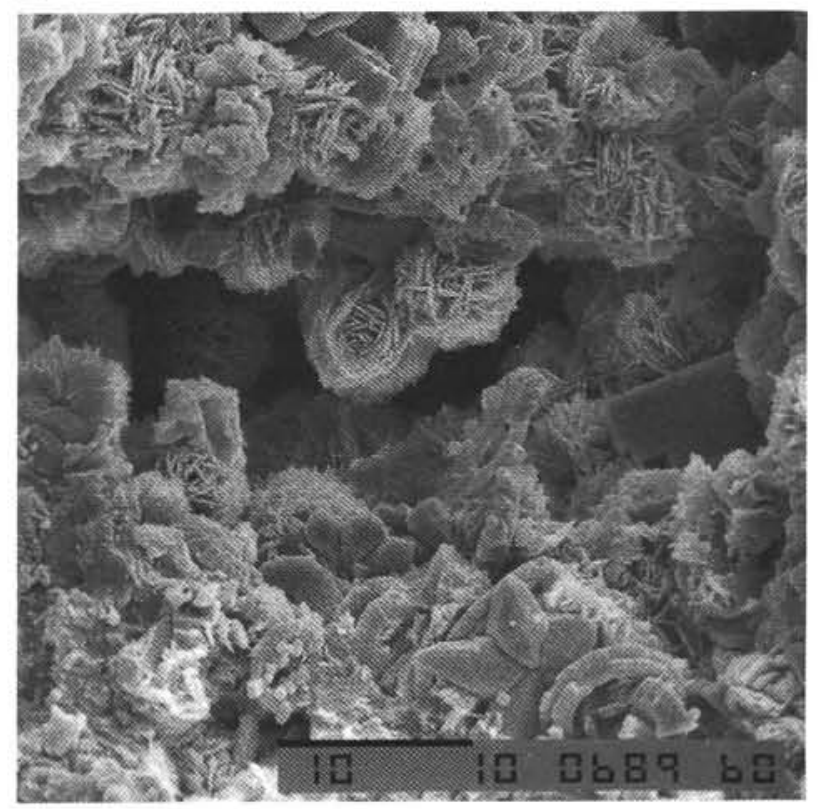

4

Plate 2. SEM photomicrographs; scales in micrometers. 1. Sample 123-765C-35R-2, 110-112 cm. High-porosity fabric dominated by calcareous nannofossils filling cavity in coarse calcareous chalk. 2. Sample 123-765C-35R-2, 110-112 cm. Porous fabric dominated by calcareous nannofossils in calcareous chalk. 3. Sample 123-765C-19R-3, 63-66 cm. Authigenic clay partially filling fossomold in calcareous chalk. 4. Sample 123-765C-19R-3, 63-66 cm. Authigenic clay and dolomite partially filling oversized cavity in calcareous nannofossil-rich chalk. 


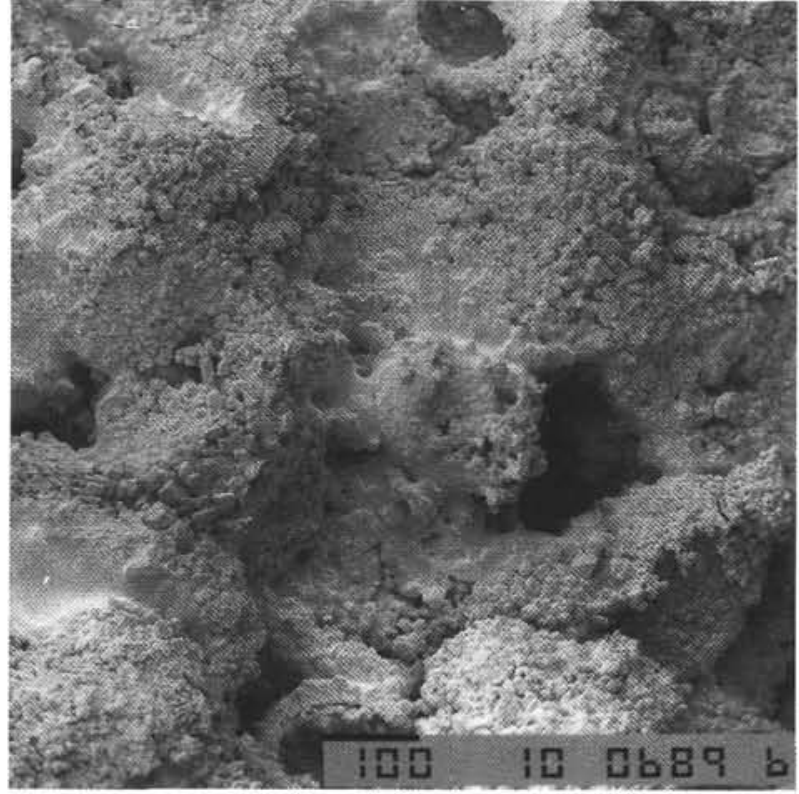

1

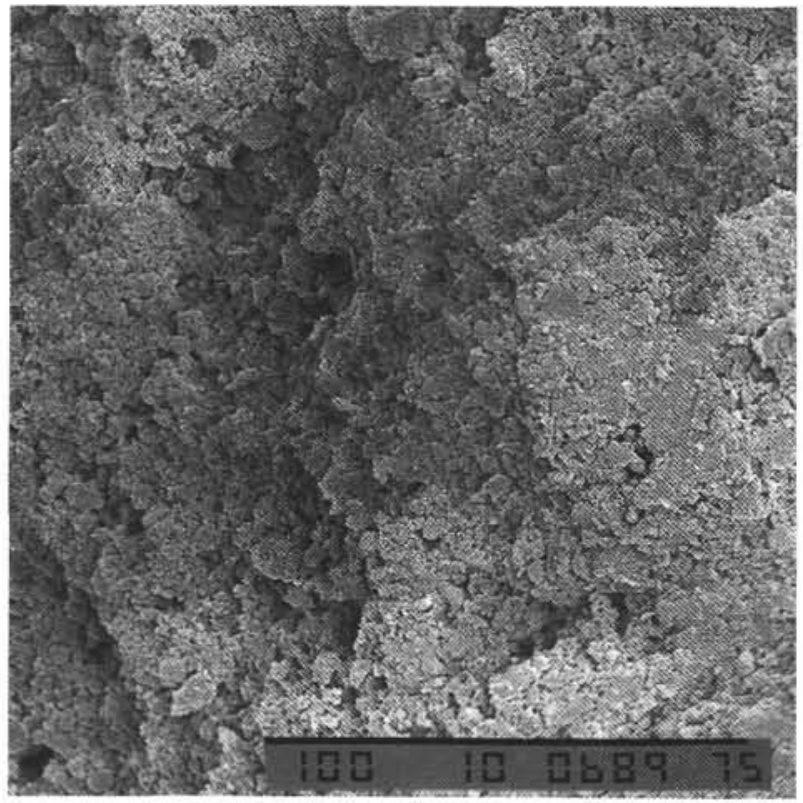

3

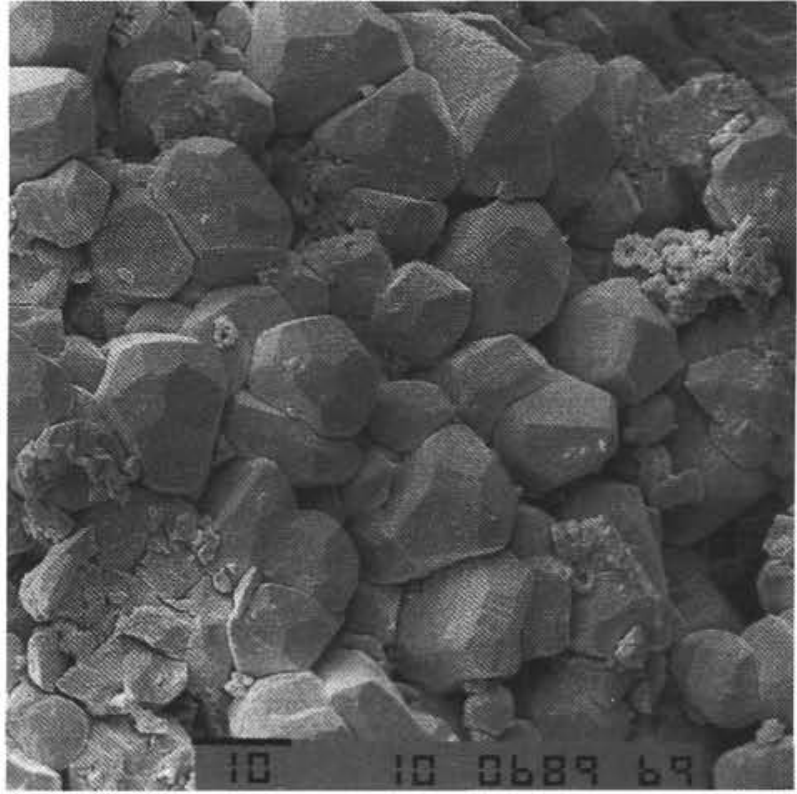

2

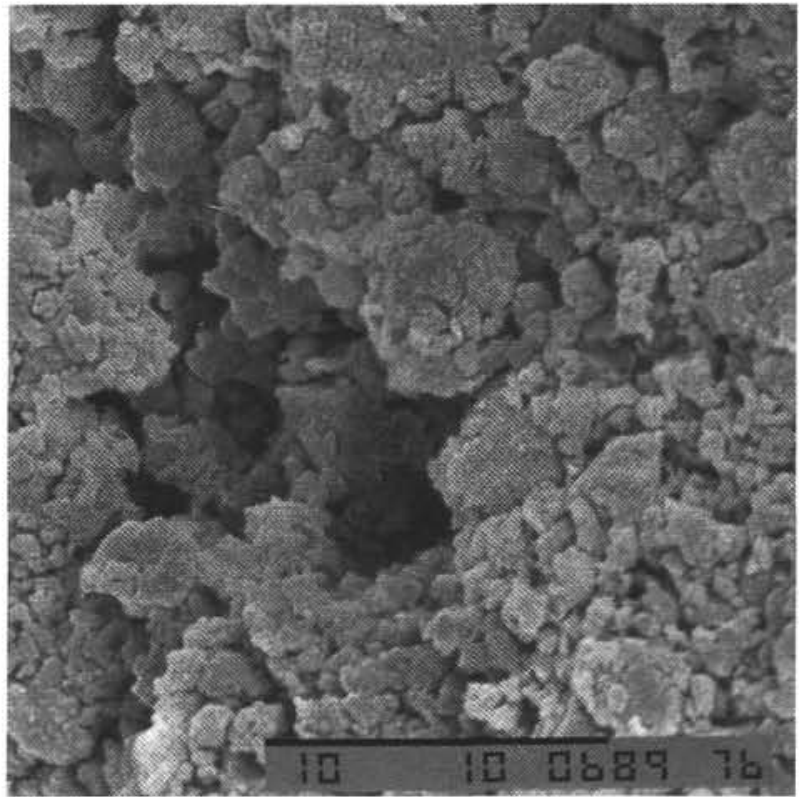

4

Plate 3. SEM photomicrographs; scales in micrometers. 1. Sample 123-765C-12R-3, 142-144 cm. Interparticle porosity in clayey calcareous chalk. 2. Sample 123-765C-12R-3, 142-144 cm. Intercrystalline microporosity within spheroidal particle in clayey calcareous chalk. 3. Sample 122-761C-23R-1, $127-130 \mathrm{~cm}$. Intercrystalline porosity in xenotopic fabric of recrystallized fossiliferous wackestone. 4 . Sample $122-761 \mathrm{C}-23 \mathrm{R}-1,127-130 \mathrm{~cm}$. Close-up of Plate 3, Figure 3. 


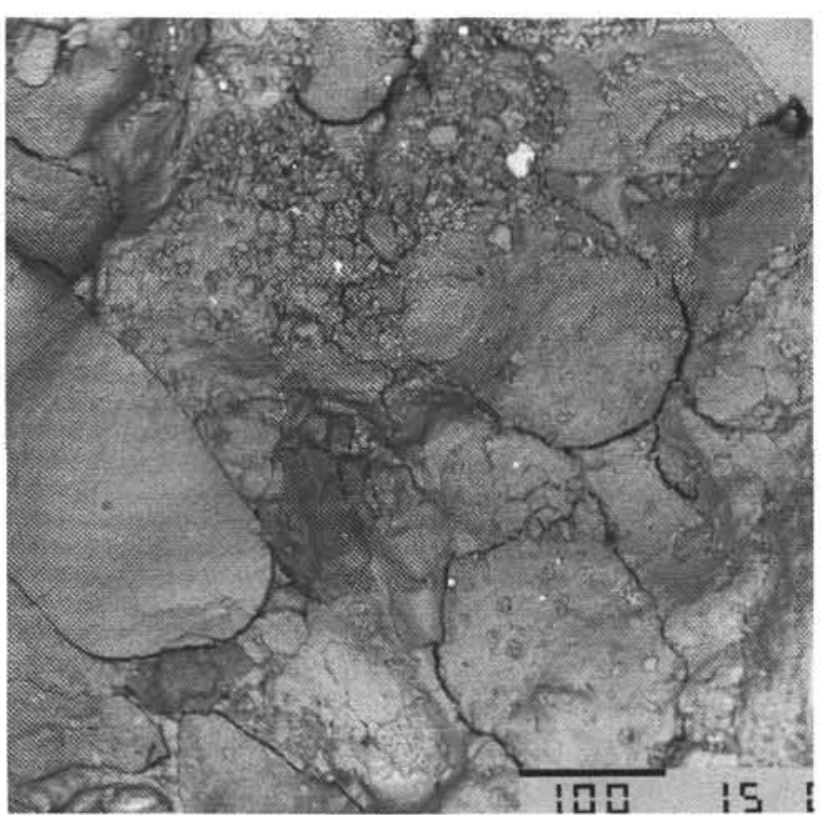

1

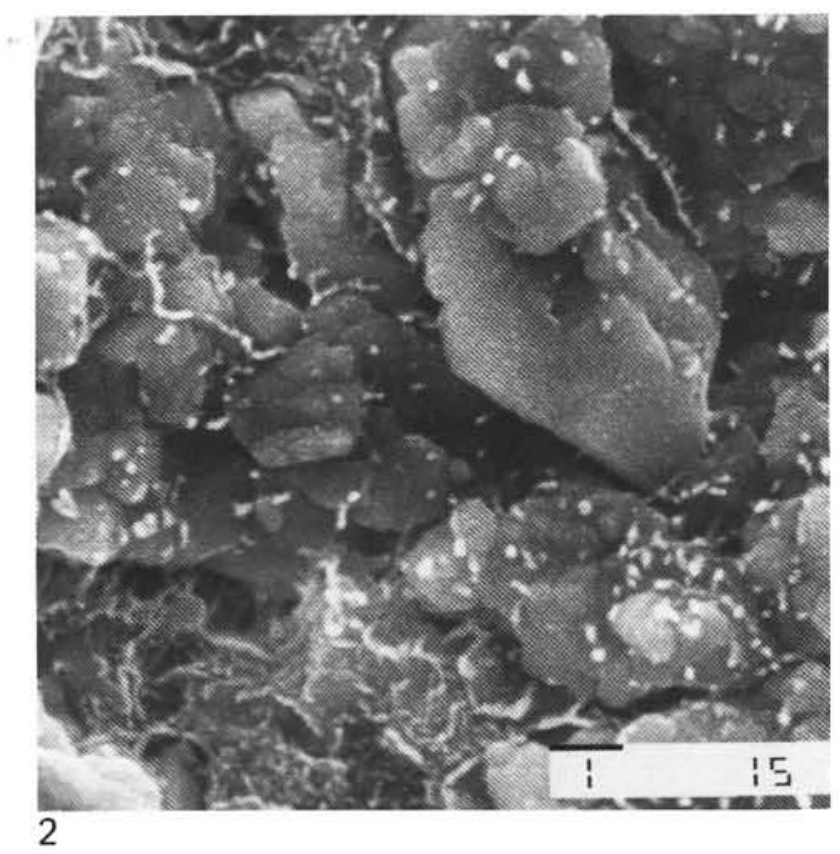
2

Plate 4. SEM photomicrographs; scales in millimeters. 1. Sample $123-766 \mathrm{~A}-42 \mathrm{R}-4,83-85 \mathrm{~cm}$. Poorly sorted polymictic sandstone. Backscatter image. 2. Sample 123-766A-43R-3, 66-68 cm. Intercrystalline microporosity within altered particle in polymictic sandstone. Note authigenic clays (white spots and curved strips). 